\title{
Fossil and subfossil records and recent status of shrikes (Passeriformes: Laniidae) in Bulgaria
}

\begin{abstract}
Zlatozar Boev
National Museum of Natural History, Bulgarian Academy of Sciences, 1 Tsar Osvoboditel Blvd, 1000 Sofia, Bulgaria, boev@nmnhs.com, zlatozarboev@gmail.com; https://orcid.org/0000-0002-8049-7509

Abstract: A total of 13 Quaternary localities of three recent species of shrikes with a total of 24 bone and bone fragments are reported. They encompass Early Pleistocene (Biharian) to Late Holocene (subrecent) and reveal the wide former distribution of Lanius collurio throughout the country. Eleven localities are situated in the Northern Bulgaria and two - in southern regions of the country. Most of the localities are located in plain and hilly landscapes and only two localities are mountainous. For each species are provided data on the chronostratigraphic distribution, altitudinal distribution and the anatomical belonging of finds. Localities of L. collurio are located between 50 and $130 \mathrm{~m}$ a.s.1.
\end{abstract}

Keywords: Balkan Peninsula, history of Bulgaria's nature, palaeoenvironment, passerines, Quaternary birds

\section{Introduction}

Although the oldest fossil record of shrikes (Laniidae Swainson, 1824) has originated from Europe (Late Miocene from Polgardi 2, Hungary, see Mlíkovský, 2002; Middle Miocene from Felsőtárkány-Felnémet, Hungary, see Kessler \& Janos, 2012), at present it is believed that the family of shrikes originated in the Australasian region (Josef, 2008). The family's Pleistocene fossil records are abundant in Europe, but most of the localities are concentrated in the southern parts of the continent (Tyrberg, 1998). Shrikes have been well known in the Quaternary in the Balkan states. Bulgaria has one of the richest fossil record regarding shrikes both on the Balkan Peninsula and in Europe.

Towards 2015, a total of six species of shrikes have been established in the recent avifauna of Bulgaria: red-backed shrike (Lanius collurio Linnaeus, 1758), isabelline shrike (Lanius isabellinus Hemprich et Ehrenberg, 1833), lesser grey shrike (Lanius minor

Received: 10 March 2020 • Editor: Peter Shurulinkov
Gmelin, 1788), great grey shrike (Lanius excubitor Linnaeus, 1758), woodchat shrike (Lanius senator Linnaeus, 1758) and masked shrike (Lanius nubicus Lichtenstein, 1823) (Ivanov et al., 2015). The paper aims to present for the first time data on the fossil records of shrikes in the country.

\section{Results and discussion}

Red-backed shrike Lanius collurio Linnaeus, 1758

At present, L. collurio is a migratory species from the southern regions of the boreal zone to the temperate zone in the Western Palearctic. The species inhabits open lands with dry soils and scattered thorny shrub and trees, steppes and semideserts (Harrison, 1982). The $16^{\circ} \mathrm{C}$ July isotherm limits its breeding range. The red-backed shrike is an indicator for sunny, warm and dry high-grassy habitats (Cramp \& Perrins, 1993). 
Table 1. Localities, finds and age of the fossil and subfossil record of shrikes in Bulgaria.

\begin{tabular}{|c|c|c|c|c|c|c|}
\hline No. & Locality & Province & Altitude (m a.s.l.) & Age & Type and number of finds & Reference \\
\hline \multicolumn{7}{|c|}{ Lanius collurio Linnaeus, 1758} \\
\hline 1 & $\begin{array}{l}\text { Cherdzhenitsa } \\
\text { Cave }-1\end{array}$ & Lovech & 200 & $\begin{array}{l}\text { Early Pleistocene } \\
\text { (Biharian) }-1,6 \mathrm{Ma}\end{array}$ & $\begin{array}{l}\text { NMNHS } 1133 \text { humerus dex.; } \\
\text { NMNHS } 1134 \text { humerus sin. }\end{array}$ & Boev (1999a) \\
\hline 2 & Cave No 16 & Lovech & 200 & $\begin{array}{l}\text { Late Pleisocene (Riss- } \\
\text { Wurmian - begining of the } \\
\text { Pleniglacial - 2) - } 40000- \\
18000 \text { A.D. }\end{array}$ & NMNHS 814 humerus dex. prox. & Boev (1999a, b) \\
\hline 3 & Kozarnika Cave & Vidin & 480 & $\begin{array}{l}\text { Late Pleistocene } \\
(80000-16000 \text { B.P. })\end{array}$ & NMNHS 9662 ulna dex. dist. & Boev (2001) \\
\hline 4 & $\begin{array}{l}\text { Temnata Dupka } \\
\text { Cave }\end{array}$ & Lovech & 200 & $\begin{array}{l}\text { Late Pleistocene } \\
\text { (Epigravettian }-31900- \\
13600 \text { B.P.) }\end{array}$ & NMNHS 4698 humerus dex. dist. & Boev (1994) \\
\hline 5 & Kozarskata Cave & Sofia & 550 & $\begin{array}{l}\text { Late Pleistocene } \\
\text { (Pleniglacial - 2) }\end{array}$ & NMNHS 11434 tbt. sin. dist. & Boev (1999a) \\
\hline 6 & Pisanets & Ruse & 100 & Late Pleistocene & $\begin{array}{l}\text { NMNHS } 16127 \text { mand. dex. prox.; } \\
\text { NMNHS } 16128 \text { cmc dex.; } \\
\text { NMNHS } 16129 \text { phal. prox. dig. maj. } \\
\text { sin.; } \\
\text { NMNHS } 16130 \text { femur sin. }\end{array}$ & $\begin{array}{l}\text { Mitev }(2004, \\
2016 a, b)\end{array}$ \\
\hline 7 & Madara - 1 & Shumen & 500 & $\begin{array}{l}\text { Early Holocene (?10 000- } \\
7000 \text { B.P.) }\end{array}$ & $\begin{array}{l}\text { NMNHS } 15986 \text { humerus sin.; } \\
\text { NMNHS } 15988 \text { humerus sin. prox.; } \\
\text { NMNHS } 15987 \text { ulna dex. }\end{array}$ & Boev (1999a) \\
\hline 8 & Orehite & Dobrich & & Middle Holocene & NMNHS 6520 humerus sin. & Boev (1999a) \\
\hline 9 & Madara - 2 & Shumen & 500 & Late Holocene & $\begin{array}{l}\text { NMNHS } 16341 \text { mandibula dex. prox.; } \\
\text { NMNHS } 16039 \text { mandibula dist.; } \\
\text { NMNHS } 16041 \mathrm{cmc} \text { dex. }\end{array}$ & $\begin{array}{l}\text { Mitev (2004, } \\
\text { 2006, 2016b) }\end{array}$ \\
\hline 10 & Shirokovo & Ruse & 150 & Late Holocene & NMNHS 12768 tbt sin. prox. & $\begin{array}{l}\text { Mitev (2004, } \\
\text { 2016b) }\end{array}$ \\
\hline 11 & $\begin{array}{l}\text { Pop-Martinova } \\
\text { Cave }\end{array}$ & Ruse & 50 & Late Holocene & NMNHS 14742 syns. corp. vert. & $\begin{array}{l}\text { Mitev }(2004, \\
2016 b, c)\end{array}$ \\
\hline 12 & $\begin{array}{l}\text { Tyovnata Dupka } \\
\text { Cave }\end{array}$ & Smolyan & 1300 & Late Holocene & NMNHS 470 coracoid sin. & Boev (1999a) \\
\hline 13 & Strelkovo & Silistra & 100 & Late Holocene & NMNHS 15776 tmt sin. dist. & $\begin{array}{l}\text { Mitev (2004, } \\
\text { 2016b) }\end{array}$ \\
\hline \multicolumn{7}{|c|}{ Lanius minor Gmelin, 1788} \\
\hline 14 & Shirokovo & Ruse & 150 & Late Holocene & NMNHS 12732 humerus dex. prox. & $\begin{array}{l}\text { Mitev (2004, } \\
\text { 2016b) }\end{array}$ \\
\hline 15 & $\begin{array}{l}\text { Pop-Martinova } \\
\text { Cave }\end{array}$ & Ruse & 50 & Late Holocene & NMNHS 14726 tbt sin. & $\begin{array}{l}\text { Mitev }(2004, \\
2016 b, c)\end{array}$ \\
\hline \multicolumn{7}{|c|}{ Lanius excubitor Linnaeus, 1758} \\
\hline 16 & Shirokovo & Ruse & 150 & Late Holocene & $\begin{array}{l}\text { NMNHS } 12725 \text { (aff. L. excubitor) } \\
\text { tmt sin. }\end{array}$ & $\begin{array}{l}\text { Mitev (2004, } \\
\text { 2016b) }\end{array}$ \\
\hline
\end{tabular}

Status in Bulgaria: in the recent Bulgarian avifauna, the species is breeding and migratory. During migration, $L$. collurio is common throughout all the country (Ivanov, 2011), except the highest mountain regions.

Fossil records in the Western Palaearctic: fossil remains of $L$. collurio are known from Austria,
Croatia, Czech Republic, France, Germany, Hungary, Moldova, Romania, Ukraine and the United Kingdom (Tyrberg, 1998).

Chronostratigraphic distribution: Early Pleistocene (Romania) to recent (Mlíkovský, 2002).

Altitudinal distribution (fossil, subfossil) in Bulgaria: 50-1300 m a.s.1. (Table 1). 
Fossil and subfossil records and recent status of shrikes (Passeriformes: Laniidae) in Bulgaria

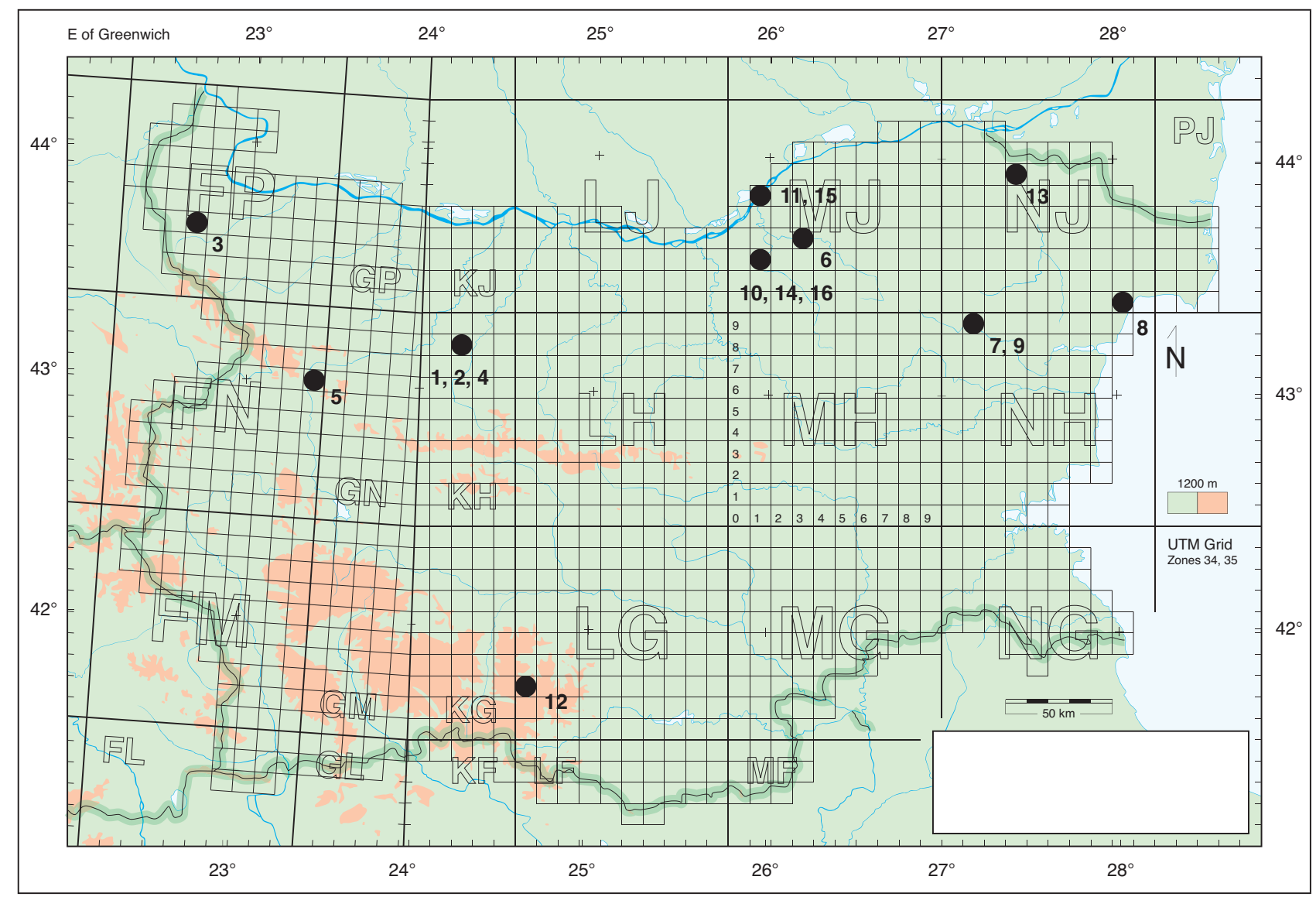

Fig. 1. Quaternary distribution of shrikes in Bulgaria (ref. to Table 1): Cherdzhenitsa Cave - 1 (1), Cave No 16 (2), Kozarnika Cave (3), Temnata Dupka Cave (4), Kozarskata Cave (5), Pisanets (6), Madara - 1 (7), Orehite (8), Madara - 2 (9), Shirokovo (10), Pop-Martinova Cave (11), Tyovnata Dupka Cave (12), Strelkovo (13), Shirokovo (14), Pop-Martinova Cave (15), Shirokovo (16).

Fossil record in Bulgaria: Early Pleistocene to Late Holocene - 13 localities (Fig. 1), seven provinces, 21 bone finds (Table 1).

Lesser grey shrike Lanius minor Gmelin, 1788

In the Western Palaearctic, L. minor is a breeding bird in the drier temperate zone. It winters in subtropical to tropical zones in Africa, south of the Sahara Desert (Harrison, 1982). Inhabits "grassy areas with more tall trees, and in more forested areas than the great grey shrike" (Harrison, 1982: 214), forest edges, dry grass steppes and landscapes with scattered trees, parklands and orchards.

Status in Bulgaria: widespread throughout the country mainly in the plain and hilly areas up to 900 $\mathrm{m}$ a.s.l. (Ivanov, 2011).
Fossil records in the Western Palaearctic: fossil remains of L. minor are known from Greece, France, Montenegro, Romania, Hungary and Spain (Tyrberg, 1998, 2008).

Chronostratigraphic distribution:Early Pleistocene (Romania and Greece) to recent (Mlíkovský, 2002).

Altitudinal distribution (fossil, subfossil) in Bulgaria: $50-150 \mathrm{~m}$ a.s.l. (Table 1).

Fossil records in Bulgaria: Late Holocene - three localities (Fig. 1), one province, two bone finds (Table $1)$.

Great grey shrike Lanius excubitor Linnaeus, 1758

At present, L. excubitor is a migrant and resident bird in the Western Palaearctic. It breeds in drier subarctic to tropical zones and winters in temperate to tropical 
zones. Inhabits partly open areas with scattered trees and tall shrubs from the scrub and forest tundra to the mixed and broadleaf forest, moorland and dry hillsides (Harrison, 1982).

Status in Bulgaria: regularly wintering but in small numbers and highly dispersed. Single specimens are found in winter in many regions of the country (Ivanov, 2011). Lanius excubitor is a critically endangered species according to the Bulgarian Red Data Book (Nikolov, 2015).

Fossil records in the Western Palaearctic: fossil remains of L. excubitor are known from Israel, Austria, Germany, Czech Republic, Croatia, France, Poland, Russia, Slovenia and Spain (Tyrberg, 1998, 2008).

Chronostratigraphic distribution: Early Pleistocene (Israel) to recent (Tyrberg, 1998).

Altitudinal distribution (fossil, subfossil) in Bulgaria: $50 \mathrm{~m}$ a.s.l. (Table 1).

Fossil record in Bulgaria: Late Holocene - one locality (Fig. 1), one province, one bone find (Table 1).

\section{Conclusions}

Skeletal representation indicated that in the collected bone material the most numerous were humeral bones (8), followed by tibiotarsi (3) and mandibles (3). A total of ten skeletal elements were represented in the Bulgarian fossil record.

Obviously, L. minor and L. excubitor were not abundant in the Pleistocene and the (Early) Holocene in Bulgarian localities of the Quaternary avifauna. We can explain that by the underrepresentation of the lesser to medium- sized passerines due to usual common taphonomic reasons. It is important to note that all of the studied localities were former feeding places of the Eurasian eagle-owl Bubo bubo (Linnaeus, 1758), which determines the frequency of shrike bone remains in the deposits. Eagle-owl hunts within a range of $50 \mathrm{~km}^{2}$ from its nest during the breeding season and sometimes the prey may be captured 5-7 km away from the nesting site or feeding place.

All Quaternary localities (except for Shirokovo for $L$. excubitor) lie within the present species breeding range. The site of $L$. excubitor is among the southernmost localities of that species in the Palaearctic (along with the sites in Mallorca, Azerbaijan and Israel, see Tyrberg, 1998).

Although not very numerous, the fossil records of shrikes complete the scanty knowledge on the Pleisto- cene and Holocene paleoenvironment in the region of its localities in Bulgaria. In the surroundings of each of them, the former distribution of the broadleaved scattered trees and tall shrubs and open- grass meadows is confirmed by the established skeletal remains of shrikes.

\section{References}

Boev Z. 1994 The Upper Pleistocene Birds. In: Kozlowski J.K., Laville H., Ginter B. (eds) Temnata Cave. Excavations in Karlukovo Karst Area, Bulgaria. Jagellonian University Press, Cracow 12: 55-86.

Boev Z. 1999a Neogenski i kvaternerni ptitsi (Aves) ot Bulgaria. Bulgarian Academy of Sciences, National Museum of Natural History D. Sci. Thesis, Sofia, 243 pp. (In Bulgarian)

Boev Z. 1999b The Late Pleistocene avifauna of Cave No 16 (NW Bulgaria) and its palaeoecological implication. In: 8th Internat. Congr. on the Zoogeography and Ecology of Greece and Adjacent Regions, Kavala, 17-21.05.1999. 8th ICZEGAR Abstracts. Hellenic Zoological Society, 21-22.

Boev Z. 2000 Early Pleistocene and Early Holocene avifauna of the Cherdzhenitsa Cave, Northwestern Bulgaria. Historia naturalis bulgarica 11: 107116.

Boev Z. 2001 Late Pleistocene birds from the 43 Kozarnika Cave (Montana District; NW Bulgaria). In: Delchev P., Shanov St., Benderev Al. (eds) Karst. Vol. I. Proceedings of the First National Conference on Environment and Cultural Heritage in Karst. Sofia, 10-11.11.2000. Earth and Man National Museum. Association of Environment and Cultural Heritage in Karst. Sofia, 113-128.

Cramp S., Perrins S.M. (eds) 1993 Handbook of the Birds of Europe, the Middle East and North Africa. The Birds of Western Palearctic, Vol. VII. Flycatchers to Shrikes. Oxford University Press, $1-586$.

Harrison C.J.O. 1982 An Atlas of the Birds of the Western Palearctic. Princeton University Press, Princeton, New Jersey, 1-332.

Ivanov B. 2011 Fauna Bulgarica, vol. 30 Aves, Part III. Academic Publishing House "Professor Marin Drinov", Sofia, 1-410.

Ivanov B., Iankov P., Boev Z., Georgiev D. Profirov L., Dimitrov M. 2015 List of the birds recorded 
in Bulgaria (Bulgarian List). (1-23). http://www. bunarco.org/bg/dokladi.html

Josef R. 2008 Family Laniidae (Shrikes). In: del Hoyo J., Elliott A., Christie D.A. (eds) Handbook of the Birds of the World. Vol. 13. Penduline-tits to Shrikes. Lynx Edicions, Barcelona, 732-798.

Kessler J., Janos H. 2012 The avifauna in North Hungary during the Miocene. Part II. Bulletin of the Hungarian Geological Society 142/2: 149-168.

Mitev I. 2004 Subfosilna fauna ot ptitsi i bozaynitsi (Aves et Mammalia - Vertebrata) ot nahodishta V Severoiztochna Bulgaria. Bulgarian Academy of Sciences, National Museum of Natural History Ph. D. Thesis, Sofia, 269 pp. (In Bulgarian)

Mitev I. 2016a Subfossil materials of birds and mammals from a site of the Tawny Owl (Strix aluco L.) near Pisanets village (Ruse Region). In: Boev Z. (ed.) Ivan Mitev - Collected Works, Vol. 1. Bulgarian Nature. Logis Publ. House, Sofia, 859-888. (In Bulgarian)

Mitev I. 2016b Subfossil fauna of birds and mammals (Aves et Mammalia - Vertebrata) from localities of Northeastern Bulgaria. In: Boev Z. (ed.) Ivan Mitev - Collected Works, Vol. 1. Bulgarian Nature. Logis Publ. House, Sofia, 203-691. (In Bulgarian)
Mitev I. 2016c Subfossil birds and mammals from two localities along the Danube River (Ruse Region, NE Bulgaria). In: Boev Z. (ed.) Ivan MitevCollected Works, Vol. 1. Bulgarian Nature. Logis Publ. House, Sofia, 844-858. (In Bulgarian)

Mitev I., Boev Z. 2006 Food spectrum of the Eagle Owl (Bubo bubo (L., 1758)) (Aves: Strigiformes) from two Holocene localities in NE Bulgaria. Historia naturalis bulgarica 17: 153-165. (In Bulgarian)

Mlíkovský J. 2002 Cenozoic Birds of the World. Part 1: Europe. Ninox Press, Praha, 1-406.

Nikolov B. 2015 Great Grey Shrike Lanius excubitor Linnaeus, 1758. In: Golemanski V. (Editor-inChief). Red Data book of the Republic of Bulgaria. Volume 2. Animals. IBER-BAS \& MOEW, Sofia, 98.

Tyrberg T. 1998 Pleistocene Birds of the Palearctic: a Catalogue. Publications of the Nuttall Ornithological Club, 27, Published by the Club, Cambridge Massachusetts, $720 \mathrm{pp}$.

Tyrberg T. 2008 Supplement to "Pleistocene birds of the Palearctic". http://web.telia.com/ u11502098/ pleistocene.pdf 